Pamiętnik Literacki 2021, 1, s. 89-110

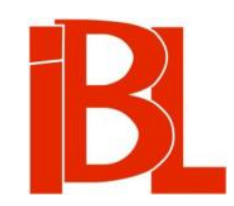

\title{
Ku hermeneutyce i etyce niemożliwej. Kafka i Gombrowicz
}

\author{
Marian Bielecki
}


Pamiętnik Literacki CXII, 2021, z. 1, PL ISSN 0031-0514

DOI: $10.18318 / \mathrm{pl} .2021 .1 .6$

MARIAN BIELECKI Uniwersytet Wrocławski

\section{KU HERMENEUTYCE I ETYCE NIEMOŻLIWEJ KAFKA I GOMBROWICZ}

Bucowi (2015-2020)

Franz Kafka w liście do Mileny Jesenskiej zawarł taką oto opowiastkę:

Mimo wszystko pisanie jest dobrą rzeczą, czuję się spokojniej aniżeli dwie godziny temu na zewnątrz na leżaku z Pani listem. Leżałem tam, krok ode mnie jakiś żuk upadł na grzbiet i był w rozpaczy, że nie może wstać. Byłbym mu chętnie pomógł, tak łatwo było mu pomóc; oczywistej pomocy można mu było udzielić jednym krokiem i lekkim popchnięciem, ale ja zapomniałem o żuku nad Pani listem, nie mogłem również wstać i dopiero jaszczurka sprawiła, że znowu zacząłem dostrzegać otaczające mnie życie. Jej droga wiodła przez żuka, który był już całkiem nieruchomy. A zatem, powiedziałem sobie, nie był to żaden nieszczęśliwy wypadek, tylko pasowanie się ze śmiercią, rzadkie widowisko naturalnego zwierzęcego umierania; ale gdy jaszczurka przepełzła po nim, postawiła go na nogi. Leżał jeszcze wprawdzie chwile jak nieżywy, lecz potem, jakby to było samo przez się zrozumiałe, pobiegł w górę po murze domu. Prawdopodobnie dzięki temu nabrałem jakoś odwagi, wstałem, napiłem się mleka i napisałem do Pani ${ }^{1}$.

Czy Gombrowicz nawiąuje do tej opowiastki w swojej słynnej przygodzie z żukami na plaży (D-2 52-54²)? Czy mamy tu do czynienia z „literackim wpływem”3? Listy do Mileny opublikowano po niemiecku w roku 1952, ale Gombrowicz w tym języku nie czytał. Po polsku ukazały się dopiero w roku śmierci pisarza, natomiast premiera francuska to rok 1956. Rok wcześniej zostały jednak wydrukowane po hiszpańsku w Buenos Aires. Dziennikowy fragment datowany jest na rok 1958. Wszystko wydaje się zatem możliwe. Czy Gombrowicz w ogóle jakoś tematyzował ewentualną zależność artystyczną od Kafki? W roku 1966 w wywiadzie dla „Le Figaro” wspominał: „Kafkę poznałem dość późno. Podziwiam go, ale często mnie nudzi”

1 F. Kafka, Listy do Mileny. Przeł. F. Ko nopka. Przedm. Z. Bieńkows ki. Wyd. 2. Kraków 1969, s. 24-25.

2 Cytaty z książek W. G o m b r o w i c za opatruję następującymi skrótami: D-1 = Dziennik 1953-1956. Kraków 1986; D-2 = Dziennik 1957-1961. Kraków 1986; D-3 = Dziennik 1961-1966. Kraków 1986; $\mathrm{P}=$ Proza. (Fragmenty). - Reportaże.- Krytyka literacka 1933-1939. Kraków 1995; PW = Publicystyka. - Wywiady. - Teksty różne 1963-1969. Przeł. I. Ka ni a [i in.]. Kraków 1997; W = Wspomnienia polskie. - Wędrówki po Argentynie. Kraków 1996. Ponadto w artykule stosuję skróty: A = J. D errid a, The Animal That Therefore I Am. Ed. M. L. Mallet. Transl. D. Wills. New York 2008. $-\mathrm{M}=$ I. Kant: Metafizyka moralności. Przekł., przypisy, przedm. E. Nowak. Przekł. przejrzał M. J. Si e m e k. Warszawa 2005; U = Uzasadnienie metafizyki moralności. Przeł. M. W a rt e n b e r g. Przekł. przejrzał R. In ga r d en. Warszawa 1971. Liczby po łączniku wskazują numery tomów, pozostałe - stronice.

3 H. Bloom: A Map of Misreading. New York 1980; Lęk przed wptywem. Teoria poezji. Przeł. A. Bielik-Robson, M. Szuster. Kraków 2002. 
(PW 312) ${ }^{4}$. Znowu więc żadnej pewności. Choć bardzo lubię spekulacje „wpływologiczne" 5 , to dziś już właściwie nie przykładam większej wagi do tego, czy faktycznie mam do czynienia $z$ ewidentnym nawiązaniem. Sądzę, że nie jest to postępowanie pochopne, w ostateczności takie zestawienie to zwykła praktyka komparatystyczna i jedyne ryzyko, jakie ponoszę, to ewentualność przygotowania nieprzekonującej interpretacji. Nie zatem domniemana zależność, koniec końców, staje się kontekstem czy desygnatem porównania, ale sam akt zderzenia dwóch kontekstów.

Kafkowskie interpretacje Gombrowicza maja już pewną, nader zresztą interesująca tradycję, związaną $z$ dwoma nazwiskami. Recenzję Ferdydurki Bruno Schulz napisał omalże pastiszując powieściowy dyskurs Procesu (nawiasem mówiąc, Gombrowicz imputował Schulzowi „pokrewieństwo z Kafką”〈D-3 7 $)^{6}$. Tę okoliczność zauważyła Małgorzata Klentak-Zabłocka w ciekawej komparatystycznej ksiażce, w której wspomniane dwie twórczości są dla siebie wzajemnym kontekstem interpretacyjnym ${ }^{7}$. Tymczasem Gombrowicz robił wiele, aby pozbawiać złudzeń wszystkich, którzy chcieliby go zestawiać z Kafka - inna rzecz, że była to jego stała strategia, mająca potencjalnych egzegetów tyleż deprymować, co i prowokować do takich zestawień. Przywołana uwaga krytyczna z wywiadu dla „Le Figaro” nie była niczym wyjątkowym czy odosobnionym w swej ambiwalencji. Dziennikowe zapiski zawierają komentarze wyrażające uznanie (D-1 64, 65; D-3 7, 11, 211) albo lakoniczne wzmianki o lekturze Dziennika (D-1 129) ${ }^{8}$. Innym znów razem Gombrowicz potwierdza, iż sprowokowany lekturą Dziennika Kafki, sięgnał po Proces i porównywał go ze słynną sceniczna wersją André Gide'a9 ${ }^{9}$ Szczegółów tej refleksji nie zdradza pewnie dlatego, że wszystko to było pretekstem do typowego dla niego wyznania, iż nie udało mu się przeczytać książki w całości: „olśniewa mnie słońce genialnej metafory, przebijające się przez chmury Talmudu, ale czytać stronę za stroną, nie, to nad siły” (D-1 153). To prowadzi do jeszcze bardziej obrazoburczej myśli: „dlaczego w naszym stuleciu tylu wielkich artystów napisało tyle nieczytelnych dzieł. I jakim cudem te książki nieczytelne i nie czytane zaważyły jednak na stuleciu i sa sławne” (D-1 153) ${ }^{10}$. Oczywiście, wiadomo, iż podobne filipiki Gombrowicza stano-

4 W. G o m b row i c z (Rozmowy z Dominique de Roux. Testament. Oprac. J. M a r gań s ki. Kraków 2018, s. 19) w Testamencie potwierdził, że nie znał Kafki piszac debiutanckie opowiadania.

5 M. B i e le c ki: Historia, dialog, literatura. Interakcyjna teoria procesu historycznoliterackiego. Wrocław 2010; Gombrowicziady. Reaktywacja. Warszawa 2020.

6 B. Schulz, „Ferdydurke”. W: Szkice krytyczne. Koncepcja ed. W. B ol e c ki. Koment., przypisy M. Wój cik. Oprac. jezyk. P. Sitki ewi cz. Gdańsk 2017.

7 M. Kle n tak-Zabł o c ka, Słabość i bunt. O twórczości Franza Kafki w świetle Gombrowiczowskiej koncepcji „niedojrzałości”. Toruń 2005, s. 187-191.

8 W. Go mbrowi cz w wywiadzie (w: Publicystyka. - Wywiady. - Teksty różne 1939-1963. [T. 1] $\langle 1996\rangle$, s. 353) udzielonym J. S. Pasierbowi powiedział, że w literaturze oprócz Th. Manna najbardziej ceni Kafkę.

9 Jak wspomina A. Russovich, oglądanie Procesu w tłumaczeniu A. Gide’a, w reżyserii J.-L. Barraulta to była jedyna wizyta Gombrowicza w teatrze, po spektaklu miał powiedzieć m.in.: „Ale ja nie jestem ani tak smutny, ani tak nudny jak Kafka” (cyt. za: R. G o m browi cz, Gombrowicz w Argentynie. Świadectwa i dokumenty 1939-1963. Przeł. Z. C hą dzyń s ka, A. Hus a r s ka. Kraków 2004, s. 144).

10 W innym miejscu G o m brow i c z stwierdził, że dzieła Kafki, Brocha i Joyce’a sa „odległe, niedostępne i zimne...” (D-1 347). 
wią część bardziej zasadniczej polemiki z „Wysokim Modernizmem”11. Paradoks wszakże polega na tym, że akurat Dzienniki nie sa chyba najlepszym przykładem „nieczytelności” Kafki, a ponadto owa właściwość w świetle dzisiejszej wiedzy o autorze Procesu to nie tyle ułomność, ile differentia specifica i bodaj przesłanie tego dzieła.

Znakiem firmowym Kafki jest bowiem to, co potwierdzą każdy czytelnik i każda czytelniczka jego prozy, mianowicie paradoks lektury, w której napotyka się osobliwą sprzeczność między wrażeniem pozornej ich czytelności i zrozumiałości, opartym na omalże faktograficzności i biurokratycznej oschłości poetyki, a premedytowaną niekonkluzywnością tekstu. Szczególnej antyhermeneutyczności utworów Kafki odpowiada jednocześnie zdumiewająca łatwość, $z$ jaka poddają się wpisywaniu w rozmaite konteksty interpretacyjne oraz parafrazie w różnych językach teoretycznych $^{12}$. Owa niekonkluzywność podlega nierzadko tematyzacji, zarówno na płaszczyźnie performatywności tekstu, jak i na płaszczyźnie metaliterackich komentarzy. Najczęściej w listach do Felicji Bauer, której np. o książce Rozważanie autor powiedział:

po prostu nie możesz się w niej połapać. Jest w niej rzeczywiście rozpaczliwy nieporządek, albo raczej: są to światełka słabo oświetlające jakaś nieskończoną gmatwaninę i trzeba być bardzo blisko, żeby coś zobaczyć $^{13}$.

Kiedy indziej zapytywał i wskazywał na onomastyczne gry z imionami:

Czy ty w Wyroku znajdujesz jakikolwiek sens, mam na myśli sens prosty, konkretny, dający się prześledzić? Ja takiego sensu nie znajduję i nie potrafię też niczego tam wyjaśnić. Ale jest tam wiele rzeczy zastanawiających ${ }^{14}$.

Niewiele później zadecydował: „Wyroku nie można objaśnić” ${ }^{15}$. W liście do Maksa Broda wprost stwierdził, iż hermeneutyczna niekonkluzywność stanowi tyleż właściwość tekstu, co i jego przesłanie: „głębszym sensem jest to, że takiego brak, i to chyba wystarcza" ${ }^{16}$. Zatem prawie za każdym razem Kafka w tym samym momencie zaprasza do egzegezy i przekonuje, iż jest ona niemożliwa.

Dla kafkologów owa aporetyczna właściwość była od początku tyleż oczywista, co intrygująca i inspirujacca. Już Kurt Tucholsky w 1920 roku w recenzji Kolonii karnej stwierdził: „Nie musicie pytać, co to wszystko ma znaczyć. To nie ma nic znaczyć. To nic nie znaczy" ${ }^{17}$. Nie jest to sprawa błaha, ponieważ dotyczy, jak stwierdzają autorzy kafkowskiej encyklopedii - „sabotowania tradycyjnej pozycji herme-

11 Zob. M. Bi ele c ki, Literatura i lektura. O metaliterackich i metakrytycznych pogladach Witolda Gombrowicza. Kraków 2004.

12 Metafora. Hasło w: R. T. Gray, R. V. Gros s, R. J. Go ebel, C. Ko elb, Franz Kafka. Encyklopedia. Przeł. J. Ko z a k. Warszawa 2017, s. 260.

13 F. Kafka, list do F. Bauer, z 29/30 XII 1912. W: Listy do Felicji $i$ inne z lat 1912-1916. E. Canet ti, Drugi Proces - Kafki listy do Felicji. Przeł. I. Kr ońs ka. T. 1. Warszawa 1976, s. 208.

14 F. Kafka, list do F. Bauer, z 2 VI 1913. W: jw., s. 410.

15 Ibidem, s. 413.

16 F. Kafka, list do M. Broda, z 18 VII 1916. W: Listy do rodziny, przyjaciót, wydawców. Wybór, przekł., koment. R. Urbańs ki, współpr. A. Urbańs ka. Warszawa 2012, s. 137-138.

17 P. Panter [K. Tucholsky], In der Strafkolonie. „Die Weltbühne” 1920, nr z 3 VI. Cyt. za: Ł. Mu siał, Kafka. W poszukiwaniu utraconej rzeczywistości. Wrocław 2011, s. 12. 
neutycznej”: „w wielu jego [tj. Kafki] tekstach, jak zauważył Walter Benjamin, występuje wolkige Stelle (mgliste miejsce) - miejsce radykalnego nieokreślenia, niepozwalające na domknięcie interpretacji" ${ }^{18}$. Maurice Blanchot tak ujął ową sytuację:

Teksty te [tj. Kafki] odzwierciedlają trudności lektury, która stara się uszanować zarazem zagadkę i jej rozwiązanie, nieporozumienie i jego wyjaśnienie, możliwość czytania mimo niemożliwości interpretacji. Nawet wieloznaczność nas nie zadowala, wieloznaczność jest wybiegiem, pozwalającym zaledwie na dotknięcie prawdy w ruchu, w przelocie, podczas gdy być może prawda tych utworów jest prosta i jedyna ${ }^{19}$.

Ma się rozumieć, takie niuanse tekstualne, komplikujące proces lekturowy, musiały okazać się szczególnie frapujące dla poststrukturalistów, zwłaszcza dla dekonstrukcjonistów; i olśniewająca wykładnia Jacques’a Derridy opowiadania Przed prawem właśnie aspekt wieloznaczności - sięgającej bezsensu, nieskończonego odraczania prawdy, permanentnej gry différence: odróżniania i opóźniania eksponowała $^{20}$. Podobnie sprawy widział Harold Bloom, powiadając, że Kafka uczynił „wszystko, co tylko można, by uniknąć interpretacji, co znaczy mniej więcej tyle, że interpretacji domagają się właśnie te fragmenty, w których najbardziej perwersyjnie i rozmyślnie wymyka się on wszelkiej wykładni”"21.

Czy może to mieć coś wspólnego z Gombrowiczem, który wedle mądrości powszechnej uchodzi za „Naczelnego Gombrowiczologa”, uporczywie kontrolującego komentarze na temat swoich tekstów przez ich objaśnianie ${ }^{22}$. To prawda, ale prawda jedynie częściowa. Gombrowicz nie był naiwny i doskonale sobie zdawał sprawę, że nie uda mu się ani całkowicie zawłaszczyć dyskursu na swój temat, ani nawet zapanować nad semantyką własnych tekstów, tyleż ze względu na to, co się dzieje w perspektywie odbioru i co się odbywa na płaszczyźnie samej tekstualności. Prewencyjnie zatem Gombrowicz uprzedzał owe niedogodności, przy czym wbrew pozorom wcale nie robił wszystkiego gwoli czynienia swoich tekstów czytelniejszymi. I niektóre jego pomysły w tej mierze były tak samo radykalne jak antyhermeneutyczne zabiegi Kafki. Oto w ostatecznie wycofanej przedmowie Krótkie objaśnienie do Pamiętnika z okresu dojrzewania, a także w zamieszczonym zamiast niej osobliwym motcie, zawarł coś, co bardzo przypomina przywołany wcześniej sąd Tucholsky'ego:

(Ważna uwaga! Nie należy doszukiwać się żadnych symboli. Nie ma tam żadnych symboli, są tylko skojarzenia. Trzeba to brać dosłownie tak, jak jest napisane. W ogóle nie bywam symboliczny.) Objaśnienia powyższe stanowią $\mathrm{z}$ konieczności nieścisłe i pobieżne uproszczenie tekstu, przeznaczone wy-

Hermeneutyka. Hasło w: Gray, Gross, Goebel, Koelb, op. cit., s. 179. A. Lipszyc (Sprawiedliwość na końcu języka. Czytanie Waltera Benjamina. Kraków 2012, s. 404-405) tak pisał o Benjaminowskiej wykładni Kafki: „Teksty Kafki, owszem, są przypowieściami, ale znowuż bardzo szczególnego rodzaju: są komentarzem bez tekstu komentowanego, objaśnieniem bez doktryny, czyli - znowuż - hagadą bez halachy".

19 M. Bla n ch ot, Wokół Kafki. Przeł. K. K o c j a n. Warszawa 1996, s. 55-56.

20 J. Derrida, „Przed Prawem”. W zb.: Nienasycenie. Filozofowie o Kafce. Red. Ł. Musiał, A. Ży chliński. Kraków 2011 (przeł. J. Gutorow).

21 H. Bloom, Kafka. Brak stałego miejsca zamieszkania. W zb.: jw., s. 240 (przeł. A. Bielik- Robson).

22 Ten dyskurs zaczął się w 1977 roku od klasycznego tekstu J. Sła w iń s ki ie go Sprawa Gombrowicza (w: Teksty i teksty. Kraków 2000. Prace wybrane. Red. W. B ole cki. T. 3). 
łącznie dla czytelników, niedobrze rozumiejących, „o co chodzi”. Proszę, aby nie były brane pod uwagę przez osoby, które ich nie potrzebują. Nie jest to żadna przedmowa. Rzecz prosta, im mądrzejszy czytelnik, tym i książka okaże się mądrzejsza; im zaś czytelnik głupszy i bardziej jałowy, tym i książka będzie głupsza. Możliwe też, że książka sama w sobie jest głupia ${ }^{23}$

Jego niezbyt lojalny i niezbyt życzliwy kolega tak wspominał paratekstową oprawę tomu:

Książka zaczyna się anagramem, który miał zawierać - jak to półżartem powiedział [Gombrowicz] „wielką tajemnicę” jego życia: „Ic ei leto can - wan nic”. Ponumerował litery i sylaby, z czego wychodzi: „To nic nei z cai i wa lec”. Rzeczywiście tajemniczo. Na szczęście pod anagramem wyjaśnia: „Musiałem coś wsadzić w ostatniej chwili, ponieważ usunałem przedmowę i pozostała jedna biała karta. Wolałem więc to niż cośkolwiek innego (np. dedykację). Miał to być anagram: "To wcale nic nie znaczy", ale z pośpiechu pomyliło mi się i opuściłem parę sylab”24.

Nawet jeśli względnie łatwo zlekceważyć złośliwą pobłażliwość Tadeusza Kępińskiego, to i tak wolno przypuszczać, że może to być tylko przypadkowa zbieżność i błaha facecja. Tak jednak nie jest. Niewiele później Gombrowicz pisze wszak Ferdydurkę, w której rozwinie cały szereg przemyślnych, prawdziwie antyhermeneutycznych strategii: ekstremalne parodie konwencji realistycznych, zacieranie granicy tekstu i metatekstu (autokomentarza), balansowanie w dyskursie metaliterackim na granicy serio-nie-serio, premedytowane inscenizowanie gry signifiants aż do granicy nonsensu itd., itp., by nawet sformułować konstatacje jak na speca od autokomentarza cokolwiek niespodziewana - „nie widziano jeszcze wyjaśnienia, które by nie było zaciemnieniem" 25 .

Opowiastkę $\mathrm{z}$ listu do Mileny interpretowano np. tak oto: „pisarz gra rolę boga podniesionego ponad ludzkie losy życia i śmierci”26. Nie wydaje się to słuszne. Komentatorzy podkreślali fakt, że już we wpływowej wykładni Waltera Benjamina pojawia się odteleologizowane pojęcie judaizmu ${ }^{27}$. Blanchot zauważał natomiast:

Niektóre z tych tekstów przełożono niegdyś na francuski, dodając w nich słowo „Bóg”. Ono tam nie figuruje. Słowo „Bóg” nie pojawia się w Dziennikach niemal nigdy, a w każdym razie nigdy w sposób znaczący. Nie oznacza to, że te pełne niepewności inwokacje nie miały charakteru religijnego, ale trzeba w nich uszanować siłę owej niepewności i nie odbierać Kafce rezerwy, którą zachowywał zawsze wobec tego, co było dlań najistotniejsze ${ }^{28}$.

W imię podobnej wierności wobec interpretowanego tekstu wypada zaznaczyć, iż Kafka jako bohater tego fragmentu wcale nie aspiruje do roli wszechmocnego boga, ale całkiem przeciwnie - w sposób typowy dla swoich literackich protagonistów takiej omnipotencji czy absolutnej władzy raczej się wyrzeka, sugerując przygodność przedstawionej anegdoty, nie zaś poddanie jej jakiejkolwiek regule. To

W. G o m b r ow i c z, Bakakaj i inne opowiadania. Oprac. Z. Ła p iń s ki. Kraków 2002, s. 338-339.

T. Kę p iń s k i, Witold Gombrowicz i świat jego młodości. Kraków 1974, s. 268.

W. G o mbrowicz, Ferdydurke. Oprac. W. B ole c ki. Kraków 2007, s. 7. Zob. też M. Bi ele ck i, Widma nowoczesności „Ferdydurke” Witolda Gombrowicza. Warszawa 2014, s. 90-140, 253-296.

D. M i r o n, The Animal in the Synagogue. Franz Kafka's Jewishness. London 2019, s. 25.

Zob. R. G a s c h é, Prawo Kafki. W polu sił między judaizmem a hellenizmem. W zb.: Nienasycenie, s. 349 (przeł. N. Rap p).

Blanch ot, op. cit., s. 94. 
najwyraźniej ta sama tendencja, wedle której u autora Procesu prawo zawsze jest bezprawiem, władza zawsze jest obsceniczna, a wszelkie sugestie Opatrzności, prowidencjalizmu czy uniwersalizmu od razu są kwestionowane. Dlatego rzeczony fragment listu nieźle wpisuje się w kluczowe motywy i konteksty kafkowskie, które dałoby się ująć jego własnymi słowami jako „atak na granicę”, „granice tego, co ludzkie"29. Ulubionych lub nawet obsesyjnych tematów bądź wątków jest tu zresztą więcej: udręka samotności, rozpacz bezsilności, niemożność czynu, przygodność wydarzeń, fatalizm losu, determinizm naturalny. Przy tym wszystkim męczarnia rozterki moralnej daje się, w jakiejś przynajmniej mierze, łagodzić przez literacki zapis. Tak bywało często u Kafki, dla którego pisanie było praktyką obsesyjną, przynosząca - niczym pharmakon - udrękę i ukojenie, zatrucie i uzdrowienie. Omawiany fragment jest typowy także dlatego, że zwierzęta, zwłaszcza insekty, autor Wyroku czynił nierzadko bohaterami swoich tekstów ${ }^{30}$.

Opowieść o żukach to jedna z najbardziej intrygujących historii Gombrowicza. Przyciagała uwagę zarówno pisarzy - np. Andrzeja Kuśniewicza, Czesława Miłosza, Sławomira Mrożka, Andrzeja Kijowskiego, Stefana Chwina ${ }^{31}$, jak i literaturoznawców, a w ich wykładniach dominantami były kwestie relatywizacji moralności uniwersalnej, przejmowania przez człowieka prerogatyw boskości, zawieszenia poczucia odpowiedzialności, obcości zwierząt ${ }^{32}$. Na prawach wyjątku wymienić wypada pionierską interpretację Anny Barcz wykorzystująca narzędzia animal studies i czytajaca ową scene jako jedno z kilku podjętych przez Gombrowicza nieudanych usiłowań wyjścia poza antropocentryczny świat ${ }^{33}$. Powiedziano o tym fragmencie dość dużo i niełatwo proponować konkurencyjną wykładnię. Owym

F. Ka fka, Dzienniki 1910-1923. Cz. 1-2. Przeł. J. Werter. London 1993, s. 224 (cz. 2), s. 57 (cz. 1). W podobnym sensie G. S c hole m (Żydzi i Niemcy. Eseje, listy, rozmowa. Przeł. M. Zaw a n ow ska, A. Li p s zy c. Wybór, oprac., przedm. A. Li p s zy c. Sejny 2006, s. 292) w liście do W. Benjamina pisał, że teksty Kafki stanowią „przypadek graniczny” religii.

30 Jedno z metaliterackich objaśnień tej predylekcji łatwo uzgodnić $\mathrm{z}$ antropologicznymi przeświadczeniami Gombrowicza: „Każdy żyje za kratami, które nosi w sobie. Dlatego teraz pisze się tak dużo o zwierzętach. Jest to wyrazem tęsknoty za wolnym, naturalnym życiem. Jednakże naturalnym życiem dla człowieka jest przecież życie ludzkie" (G. J a n o u c h, Rozmowy z Kafka. Notatki i wspomnienia. Przeł. J. B ory siak, E. Dy c zek. Posł., przypisy E. Dy czek. Warszawa 1993, s. 43).

31 A. Ku śn i e wi c z, Eroica. Łódź 1995, s. 50. - Cz. Miło s z, Widzenia nad Zatoka San Francisco. Kraków 2000, s. 81. - S. Mroż e k, Dziennik. T. 3: 1980-1989. Kraków 2013, s. 125. - S. Le m, S. M rożek, Listy. 1956-1978. Wstęp J. J a z zę b s ki. Kraków 2011, s. 235-236. - A. Kij ows ki, Sumienie rozszerzone i sumienie sztuczne. W: Gdybym był królem. Poznań 1988, s. 20-21. S. Chwi n, Kartki z dziennika. Gdańsk 2004, s. 317-318.

Zob. B. Zielińs ka, Gombrowicz i ból. Fantazje na ustugach diabła. W: Namysty i pomysty. Szkice o literaturze współczesnej. Warszawa 1995, s. 31. - Z. Ła p iń s k i, Ja, Ferdydurke. Kraków 1997, s. 114. - J. J a rz ę b s ki: Literatura jako forma istnienia. (O „Dzienniku” Gombrowicza). W: Podgladanie Gombrowicza. Kraków 2000; Trudno być Bogiem. W zb.: jw., s. 172, 198; Gombrowicz i natura. W: Natura i teatr. 16 tekstów o Gombrowiczu. Kraków 2007, s. 60-61. - Kl e n t a k - Z a bł o c ka, op. cit., s. 222-224. - J. M a d ej s ki, „Wystawianie duszy na niebezpieczeństwa”. Gombrowicz Chwina. W zb.: Gombrowicze. Red. B. Ży n i s. Słupsk 2006. - Ł. Tis c h n e r, Gombrowicza milczenie o Bogu. Kraków 2013, s. 201. - S. W ró b e 1, Polska pozycja depresyjna. Od Gombrowicza do Mrożka i z powrotem. Kraków 2015, s. 281-282. - S. P o r z u c z e k, Mapowanie bólu. Lektura, spojrzenie, afekt. Kraków 2020, s. 107-108.

33 A. B a rc z, Człowiek i zwierze - problem granicy w „Dziennikach” Gombrowicza. W: Realizm ekologiczny. Od ekokrytyki do zookrytyki $w$ literaturze polskiej. Katowice 2016, s. 220. 
nierzadko wnikliwym, w wielu miejscach błyskotliwym komentarzom można by wytknąc chyba to tylko, że sprowadzaja zamierzenie Gombrowicza - tym samym wpisując się w tendencję dominującą w gombrowiczologii - do strategii demaskacji, demistyfikacji, dekonstrukcji. Do pewnego stopnia jest to słuszne, bo Gombrowicz faktycznie coś takiego tu robi, dla mnie jednak takie postrzeganie go wydaje się od jakiegoś czasu niewystarczające i redukcyjne, i to nie tylko dlatego, że stąd już bardzo blisko do zarzutów, a właściwie etykiet w rodzaju cynicznej deprawacji, nihilistycznej destrukcji, postmodernistycznego permisywizmu itp.

Chciałbym więc, nie tracąc $z$ pola uwagi tego, co jest w przywoływanym fragmencie de-konstrukcją, wyinferować z niego, w miarę możliwości, jakąś pozytywność albo nawet coś w rodzaju konstruktywnego czy afirmatywnego przesłania. Jeśli stwierdził Jerzy Jarzębski, że opowiastka ta przedstawia „bankructwo abstrakcyjnej "uniwersalnej etyki" "34, to ową trafną sugestię dałoby się dopowiedzieć czytając ją (tę opowiastkę), nb. podobnie jak to się często zdarza z przypowieścią Kafki Przed Prawem $^{35}$, jako polemike $\mathrm{z}$ najsłynniejszą chyba koncepcją moralności wypracowaną przez Immanuela Kanta ${ }^{36}$. W Uzasadnieniu metafizyki moralności królewiecki filozof zadecydował o połączeniu zobowiązania etycznego i prawa: „O b o w i a z e k jest koniecznościa czynu wypływającego z poszanowania prawa" (U 21). Dlatego prawo moralne wymaga bezwzględnego posłuszeństwa: „Każdy musi przyznać, że prawo, jeżeli ma obowiązywać moralnie, tj. jako podstawa zobowiązania, musi się odznaczać absolutną koniecznością" (U 5). Nie może być więc sprawą interpretacji - ta bowiem jest czymś przygodnym i historycznym. Tymczasem prawo przynależy do porządku abstrakcji, obiektywności, bezinteresowności, powszechności i powtarzalności. W swej istocie stanowi bezwarunkowy nakaz uchylający roszczenia jednostkowych pragnień. Zatem jeśli przepis w jakiejś mierze powszechny opiera się na podstawach empirycznych, może uchodzić za regułę praktyczna, ale prawem moralnym być nie może. A to dlatego, że doświadczenie dostarcza wyłącznie „motywów przypadkowych” (U 58) - zmęczony umysł ma do nich szczególną skłonność, wskutek czego podrzuca moralności „bękarta zszytego z części najróżnorodniejszego pochodzenia, który jest podobny do wszystkiego, co w nim widzieć chcemy, tylko nie do cnoty, 〈zwłaszcza〉 dla tego, kto raz ją ujrzał w jej prawdziwej postaci” (U 58). Doświadczenie i imperatyw moralny są z definicji rozłączne, bo nie ma doświadczenia, które byłoby uniwersalne, nie może więc ono stanowić o tym, co ogólne (U 65) ${ }^{37}$.

J a r zę b s ki, Literatura jako forma istnienia, s. 172.

Zob. M. P. Markows ki, Przed prawem. Interpretacja, literatura, etyka. „Teksty Drugie” 2002, nr 1/2. - Derrida, „Przed prawem”. - J. Hillis Mille r, Lektura opowiadania: Kant. W zb.: Lyotard, Derrida, Hillis Miller i inni. Kalifornijska Teoria Krytyczna. Antologia tekstów. Red. E. B obrowska, M. Murawska, M. Rudkowska. Warszawa 2019, s. 273 (przeł. I. Bor uszkow s ka).

Przywołanie Kanta nie jest przypadkowe, jest nawet w jakimś sensie oczywiste. Jak wskazuje A. B a d i o u (Etyka. Przewodnik Krytyki Politycznej. Przeł. P. M o ś c i c k i. Warszawa 2009, s. 26), ogólne wyobrażenie o etyce Kantowskiej stanowi podstawę współczesnego „powrotu do etyki” i Praw Człowieka.

G. D ele uze (Filozofia krytyczna Kanta. Doktryna władz. Przeł. B. B a n a sia k. Gdańsk 1999, s. 24) pisał o tym tak: „Kryteriami a priori są konieczność i powszechność. A priori określa się jako 
Z takich samych powodów „podstawy zobowiązania nie należy [...] szukać $\mathrm{w}$ naturze człowieka ani w okolicznościach 〈zachodzacych〉w świecie, w jakim człowiek się znalazł, lecz a priori jedynie w pojęciach czystego rozumu" (U 5-6) ${ }^{38}$. Co ważne, nie dotyczy to tych, którzy nie mieszczą się w przyjętym modelu człowieczeństwa: „Tylko istota rozumna posiada władzę działania we dług przeds t a w i e ni a praw, tj. według zasad, czyli posiada wolę" (U 38). A skoro do dedukcji czynów z praw potrzeba rozumu, stąd prosty wniosek, że wola stanowi rozum praktyczny. Prawo moralne uwarunkowane jest „dobrą wolą, którą Kant uznaje za jedyna w świecie rzecz absolutnie dobra, wszystkie inne talenty umysłu czy przymioty temperamentu pozostają czymś przygodnym i relatywnym (U 11). Dobra wola ujmowana jest tutaj jako kategoria sama w sobie (analogicznie do imperatywu kategorycznego - to czyn dobry sam w sobie 〈U 41)), niezależna od swoich potencjalnych konsekwencji: celów i skutków. Jako taka stanowi wystarczający warunek tego, by człowiek zasługiwał na szczęście. Autonomia woli ma kluczową wartość i oznacza niezależność od wszystkiego, co wobec niej - tak jak to, co zanadto subiektywne - heteronomiczne: od Boga, władzy politycznej, tradycji, obyczaju etc., a jej działanie konstytuuje prawo, które potencjalnie mogłoby mieć zakres powszechny. Nic więc dziwnego, że „dobra wola” jest „wolna” - chciałoby się sparafrazować Herberta - „do pewnych rozsądnych granic”, ponieważ wpisana jest w strukturę obowiązku (U 16). Obowiązku poddania się prawu moralnemu, który stanowi tym samym urzeczywistnienie wolności.

W Krytyce rozumu praktycznego Kant zawyrokował o podmiocie prawa: „Wydaje [...] sąd, że coś może uczynić, ponieważ jest tego świadomy, że powinien to uczynić"39. A jeśli tak, to decyzja nie powinna mieć nic wspólnego z jakimikolwiek uczuciami czy naturalnymi skłonnościami, bo jeśli coś rodzi przyjemność bądź satysfakcję, to nie może mieć wartości moralnej (U 18) - czyli właśnie według Kanta jest „patologiczne”: związane $z$ pathosem, ze znoszeniem czegoś, oddaniem się popędowości i zmysłowości ${ }^{40}$. Nie zamiar a realizacja zasady, nie decyzja a koniecz-

niezależne od doświadczenia, ale właśnie dlatego, że doświadczenie nigdy nie "daje» nam niczego, co byłoby powszechne i konieczne. Słowa "wszyscy", "zawsze", "z koniecznością", lub nawet "jutro" nie odsyłają do czegoś w doświadczeniu: nie wywodzą się z doświadczenia, nawet jeśli stosują się do niego". Według Hillis a Mille r a (op. cit., s. 266) dażenie Kanta do obiektywności i uniwersalności okazało się farsą i uniwersalizacją tego, co partykularne, w tym przypadku - koncepcji moralności charakterystycznej dla określonego kontekstu historyczno-kulturowego, kraju, klasy, wyznania.

38 Na wzajemne implikacje Prawa Moralnego i Rozumu - oraz jego fundamentu: logiki, zwracał uwagę Dele uze (op. cit., s. 50-51). Stwierdzał też wprost, że Prawo Moralne „nie wymaga żadnych subtelnych rozumowań, lecz opiera się na najzwyklejszym i najbardziej powszechnym użyciu rozumu" (ibidem, s. 60-61). I jeszcze komentarz M. Heidegger a (Kant a problem metafizyki. Przekł., przedm., przypisy B. B ar a n. Warszawa 1989, s. 178): „Poddając się prawu, poddaję się sobie samemu jako czystemu rozumowi".

39 I. Ka nt, Krytyka praktycznego rozumu. Przekł., przedm., przypisy J. G a ł e c ki. Warszawa 2012, s. 52-53.

40 Na innym poziomie wyrzeczenie ascetyczne i poddanie się prawu przynosi odmienny, wyższy rodzaj satysfakcji. To w tym kontekście S. Žiž e k (Wzniosły obiekt ideologii. Przeł. J. B a tor, P. D y be 1. Wstęp P. Dy bel. Wrocław 2001, s. 103-104, 196) pisze o obsceniczności prawa, którego roszczenia są puste i czysto formalne, nie zaś wsparte jakimiś pozytywnymi treściami, a ich spełnienie się daje właśnie szczególna przyjemność. „Możesz, ponieważ powinieneś” - tak oto streszcza „im- 
ność czynu wynikającego z poszanowania prawa (U 20-21). Krótko mówiąc, żadnych „skrytych pobudek miłości własnej” (U 30), tylko dyktat czystego rozumu. Wszelkie zaś decyzje podjęte w takich okolicznościach będą konieczne obiektywnie i subiektywnie. Rozum praktyczny, „który każdorazowo wydaje werdykt o słuszności obowiązku”, jest więc tożsamy z sumieniem (M 268). Sumienie nie jest u człowieka czymś przygodnie ustanowionym, ale pozostaje „organiczną częścią jego istoty” (M 315). Nie bez znaczenia okazuje się także i to, że Rozum Praktyczny powinien być zarazem Rozumem Prawodawczym ${ }^{41}$.

Gombrowicz nie posuną się do komentarzy tak dobitnych jak Friedrich Nietzsche, pomawiający Kanta o „fanatyzm moralny” albo stwierdzający, że „imperatyw kategoryczny czuć okrucieństwem” 42 . Niemniej jednak dogmatyczny charakter Kantowskiej koncepcji moralności był dla Gombrowicza czymś oczywistym. Na marginesie rozważań o egzystencjalizmie zapytywał retorycznie:

Czy kantowskie sądy syntetyczne a priori nie miały charakteru ponadczasowego w tym sensie, że były uzależnione od samej struktury czasu? Czy Prawo Moralne nie świeciło wciąż na tym niebie, jak konstelacja wskazująca drogę? [W 271]

W Przewodniku po filozofii w sześć godzin i kwadrans lekcję Kantowskiej metafizyki moralności wykładał z kolei tak:

Sądy traktujemy tutaj jako sądy imperatywne.

$[\ldots]$

Krytyka praktycznego rozumu: chodzi o moją powinność, działanie (moralne). Imperatywy mogą być hipotetyczne lub kategoryczne.

Imperatywy 〈kategoryczne〉 są wtedy, gdy wola jest autonomiczna, tzn. przez nic nie uwarunkowana. Np. imperatyw „Trzeba być moralnym”, jest kategoryczny. Nie zależy bowiem od żadnego warunku. Gdy mówię, że powinienem być moralny, abym mógł pójść do nieba albo by mnie ludzie szanowali, to mamy tu już imperatyw hipotetyczny. Jest to ważne, bo w naszych czasach miesza się te rzeczy ze sobą.

Dla Kanta imperatyw moralny winien być bezinteresowny.

Ale moralność całkowicie zależy od woli. Tu uwaga. Są to prawa kantowskie, rozmaicie interpretowane. Przykład: Moja matka jest chora, a ja, w najlepszej woli uzdrowienia jej, podałem jej omyłkowo zabójcze lekarstwo. $Z$ moralnego punktu widzenia jestem w porządku.

Dlatego największe potwory w dziejach: Hitlera, Stalina, trzeba sądzić wedle intencji.

Gdyby Hitler uważał, że Żydzi są chorobą świata, byłby moralnie w porządku, choćby się nawet mylił. Gdyby jednak w tym, co robił, miał osobisty interes, byłoby to niemoralne. Moralność dla Kanta to wola moralna, dobra wola. [PW 67-68] ${ }^{43}$

peratyw kategoryczny” słoweński filozof. Wspomnieć należy, że Žižek podąża za wykładnią J. Lac a n a (Kanta Sadem. Przeł. T. Ko m e n d a n t. „Twórczość” 1989, nr 8).

41 Oto bodaj najbardziej znane wysłowienie tej myśli: „nie powinienem nigdy inaczej postępować jak tylkotak, żebym mógł także chcieć, aby maksyma moja stała się powszechnym prawem" (U 23). Na istotność metaforyki władzy i odniesień do kontekstów państwa i polityki u Kanta zwracał uwagę Z. Ba uman (Wieloznaczność nowoczesna, nowoczesność wieloznaczna. Przeł. J. B a u ma n. Przekł. przejrzał Z. B a u m an. Warszawa 1995, s. 37-45).

F. Ni etz s ch e: Notatki z lat 1885-1887. Przeł. M. Ko pij, G. Sowin ski. Łódź 2012, s. 376; Poza dobrem i złem. Z genealogii moralności. Przeł. P. Pi e ni ąż e k. Łódź 2018, s. 255.

43 Na temat odniesień Gombrowicza do Kanta zob. H. B e r r e s s e m, Lines of Desire. Reading Gombrowicz's Fiction with Lacan. Evanston, Ill., 1998, s. 56-78. - J. Ma rgań ski, Gombrowiczwieczny debiutant. Kraków 2001, s. 154-159. - M. G o d d a rd, Gombrowicz, Polish Modernism, and the Subversion of Form. West Lafayette, Ind., 2010, s. 57-60, 107-108. 
Poza staranną rekonstrukcją poglądów Kanta pojawia się próba „domyślenia” ich do ostatecznych, praktycznych konsekwencji ${ }^{44}$. Kategoria „dobrej woli”, wobec której Gombrowicz był zawsze podejrzliwy ${ }^{45}$, okazuje się problematyczna, jeśli poddać ją - Gombrowicz to podkreśla - próbie interpretacji, co znaczy w istocie: skonfrontować ją z konkretnymi realiami. Konsekwentna absolutyzacja intencji i ideologicznych pryncypiów prowadzi do immoralizmu ${ }^{46}$. Jeśli Kantowskie krytyki, programowo wymierzone w przesądy, ateizm, libertynizm, fanatyzm, przewidywały krytykę Rozumu, będącą w istocie namysłem nad warunkami jego możliwości, po to aby tym samym zapewnić prawomocność jego dyktatu („Nieuprawnione użycie rozumu prowadzi do dogmatyzmu, heteronomii i złudzeń” - stwierdził w związku z tym Michel Foucault ${ }^{47}$ ), to raczej zatrzymywały się przed bardziej konsekwentnym badaniem warunków niemożliwości tego systemu. Nie bez powodu. Jak wiadomo, Kant nie tylko bardzo dbał o logiczność i spójność własnego systemu metafizycznego, lecz wprowadził taki sam rygoryzm w porządek swojej egzystencji. Systematyczny plan dnia, żelazna dyscyplina umysłu i ciała („nigdy się nie pocił”, podkreślał biografista ${ }^{48}$ ). Dałoby się dziś oczywiście złośliwie sprowadzić to wszystko do poziomu zachowań fobicznych i natrętnych, ale chyba ciekawiej zastanawiać się nad ogólnymi warunkami morderczej konsekwencji Kantowskiego projektu egzystencjalnego i filozoficznego. Nie ma bowiem watpliwości, że podstawowym jego celem było egzorcyzmowanie tego, co groziło zakłóceniem: odstępstwo, relatywność, etc. A właśnie granice moralności zarysowywanej przez Kanta wydaja się chyba najciekawsze. Kiedy powiada on np. tak: „Być dobroczynnym, gdzie tylko można, jest obowiązkiem” (U 17), to niełatwo nie ulec pokusie zapytania, co z sytuacjami, „gdzie nie można”. W innym miejscu pojawia się sugestia, że dobroczynność powinna mieć swoje granice, kiedy wchodzi w konflikt $\mathrm{z}$ własnym szczęściem dobroczyńcy - i te granice jest w stanie wyznaczyć wyłącznie on sam (M 259, 336). Dokładniejsze obrysowanie podobnych granic interesowałoby zapewne Gombrowicza (i Kafkę).

S. Žižek (W obronie przegranych spraw. Przeł. J. Kutyła. Warszawa 2008, s. 217) zastrzega, że traktowanie Kantowskiej etyki bezwarunkowej powinności jako usprawiedliwienia (co zdarzyło się np. A. Eichmannowi tłumaczącemu swój udział w planowaniu Holocaustu) to nadużycie polegające na nierespektowaniu założenia autonomii moralnej i odpowiedzialności podmiotu, uniemożliwiających zrzucenie winy na jakąs postać wielkiego Innego. Wspomina o tym również $\mathrm{H}$. A r e n d $\mathrm{t}$ w książce Eichmann w Jerozolimie. Rzecz o banalności zła (Przeł. A. Szo stki ewicz. Kraków 1987, s. 174-176). Zob. też S. Chwi n, Gombrowicz i Niemcy. W zb.: Witold Gombrowicz nasz wspótczesny. Materiały międzynarodowej konferencji naukowej $w$ stulecie urodzin pisarza Uniwersytet Jagielloński - Kraków, 22-27 marca 2004. Red. J. J a rzę b ski. Kraków 2010, s. $100-115$.

Zob. M. Bi ele c ki, „Ferdydurka” $i$ „Mechaniczna pomarańcza”, czyli o nieoczywistości tego, co niektórzy nazywaja „wolna wola”. „FA-art” 2016, nr 1/2.

46 Podobną kwestię podniósł R. Ro r ty (Etyka zasad a etyka wrażliwości. Przeł. D. A b r is z ew s ka. Przekł. przejrzał A. Szahaj. „Teksty Drugie” 2002, nr 1/2, s. 62): „Bohaterowie homeryccy, nazistowscy żołnierze w obozach koncentracyjnych, właściciele niewolników sprzed wojny secesyjnej - wszyscy oni posiadali zasady. Ich zasady nie obroniły ich jednak przed nieświadomym stosowaniem okrucieństwa wobec ludzi, o których nie myśleli jako o "nas"”.

47 M. Fo u c a u lt, Czym jest oświecenie? W: Filozofia, historia, polityka. Wybór pism. Przekł., wstęp D. Leszczyński, L. Rasiński. Warszawa-Wrocław 2000, s. 282.

48 Th. de $\mathrm{Q}$ u in cey, Ostatnie dni Immanuela Kanta. Przekł., wstęp, posł. A. Przybysławski. Kraków 1996, s. 22. 
A co by było, gdyby postapić na odwrót i odczytać dziennikowy fragment przez pryzmat Kantowskiej moralności? Pomijam kwestię, że opowiastka Gombrowicza mówi jednak o zobowiązaniu wobec zwierząt, a więc bytów nierozumnych, tymczasem Kant nie watpił, iż jako takie nie obliguja one człowieka do przyznawania im jakichkolwiek praw ani do spełniania jakichkolwiek powinności względem nich: „Są to istoty nierozumne, które do niczego nas nie zobowiązują, ani też my nie mamy żadnych zobowiązań w stosunku do nich" (M 57). Kant dodał wprawdzie, że wskazane jest powstrzymywanie się od gwałtownego i okrutnego traktowania zwierząt („czyli ożywionej, ale bezrozumnej części stworzenia”, M 322) - musi się to wszakże wiązać z powinnościami człowieka wobec samego siebie, ponieważ tego rodzaju czyny osłabiaja „odruch współczucia dla istot cierpiących” (M 322) ${ }^{49}$. Niemniej rację miał Nietzsche imputujący Kantowi - a także Platonowi, Spinozie, La Rochefoucauld jednomyślność „w niskiej ocenie współczucia” ${ }^{0}$. W tej perspektywie Kant faktycznie nie cieszył się najlepszą reputacją. Jacques Derrida sytuował go w szeregu takich filozofów, jak Kartezjusz, Kant, Heidegger, Lévinas i Lacan, którzy w imię logocentrycznych inklinacji uznawali zwierzęta za istoty bezrozumne i odrębne od logosu, a więc niezdolne do komunikacji, bo pozbawione możliwości odpowiedzi (lista braków określających odrębność zwierząt jest tu dłuższa: historia, śmiech, żałoba, pochówek, dar, instytucjonalność, technika, ubranie, kłamstwo, udawanie udawania, zacieranie śladów, płacz, szacunek itd. $\langle\text { A 5, 32, 52, 81, 89, 135〉 })^{51}$. Derrida uchyla tę supozycję, traktując relację $z$ logosem jako mniej istotną $\mathrm{i}$ - za Jeremym Benthamem (A 27) ${ }^{52}$ - zapytuje, czy zwierzęta cierpią. To sprawa doniosła, bo tradycyjne konceptualizacje filozoficzne przez uwikłanie w system niesymetrycznych opozycji naznaczone były symboliczna, epistemologiczną przemoca - a jednocześnie legitymizowały przemoc najzupełniej realna. Ma się rozumieć, takie postawienie sprawy przez Derridę nie buduje opozycji człowiek-zwierzęta, ale ją dekonstruuje. Inaczej u Kanta, u którego zwierzę, jako niebędące racjonalną istotą, dla którego niemożliwa jest konstatacja ,ja myśle", stanowiąca warunek rozumienia i rozumowania, oraz z tych samych powodów pozbawione wolności oraz autonomii, nie może stać się podmiotem praw i zobowiązań (A 99). Zwierzę pozbawione jest tego, co Kant nazywa „godnościa", wewnętrznej i bezcennej jakości, celu samego w sobie, dlatego w odróżnieniu od człowieka podlega ono rynkowej wycenie (U 70-78). Jest to kalkulacja czystego praktycznego rozumu, przyjmującego ofiarę ze zmysłowości - i jak najza-

Kant jednak przyznaje człowiekowi prawo uboju zwierząt dla celów gospodarczych (we względnie humanitarnych warunkach), wykorzystywania jako siły roboczej (ale nie nad miarę ich możliwości), i zabrania fizycznych doświadczeń na zwierzętach. Uważa, że pośrednim obowiązkiem człowieka jest wdzięczność dla „leciwego konia lub psa za ich wierną służbę” (M 322). Zob. P. G u y e r, Kant o obowiazkach dotyczacych przyrody. Przeł. M. Gensle r. „Acta Universitatis Lodziensis. Folia Philosophica" t. 10 (1993).

$50 \quad$ Nietzs ch e, Poza dobrem i ztem, s. 219.

51 Zob. J. Derrida, The Beast \& the Sovereign. T. 1. Ed. M. Lis se, M. L. Mallet, G. Mich a ud. Transl. G. Benningto n. Chicago, Ill. - London 2009, s. 97-135. Zob. też M. C a la r co, Zoographies. The Question of the Animal from Heidegger to Derrida. New York 2008.

52 Chodzi o następujące słowa: „Należy pytać nie o to, czy zwierzęta mogą rozumować ani czy mogą mówić, lecz czy mogą cierpieć" (J. B en th a m, Wprowadzenie do zasad moralności i prawodawstwa. Przeł. B. Naw r o c zyń ski. Warszawa 1958, s. 420). 
sadniej Derrida mówi tu o jego potencjalnym okrucieństwie. Żadne zatem zwierzę, nawet, lub raczej zwłaszcza zwierzę w człowieku, nie może dostąpić prawa, nie może być celem, a jedynie środkiem. $Z$ tego też powodu Theodor Adorno był szczególnie nieufny wobec rzekomo przyrodzonej ludziom „godności”, służącej uzasadnieniu dominacji człowieka nad naturą i zwierzętami. Nawet więcej niż podejrzliwy, bo dokonał on kryminalizacji owej dominacji, ujmując w kategoriach nienawiści i wojny skierowanych przeciwko naturze. Derrida tak oto referował przekonania Adorna na temat autora Metafizyki moralności:

Kant nie pozostawia miejsca na współczucie ani na litość między człowiekiem a zwierzęciem (jako tym, które „może cierpieć”, jak powiedział Bentham). Adorno mówi, że nic nie jest bardziej odrażające, bardziej nienawistne, bardziej wstrętne dla człowieka Kantowskiego niż pamięć o podobieństwie lub powinowactwie między człowiekiem a zwierzęcością. Kant nienawidzi tylko zwierzęcość w człowieku. Stanowi to nawet jego „tabu”, we wszystkich sensach tego terminu, a zaczyna się jako święte zranienie przeciwko nieczystości. [...] Kantowskie określenie podmiotu ludzkiego (jedyny przykład bytu racjonalnego i skończonego, pojedynczy przykład intuitus derivativus) byłoby znakomitą formą tego transcendentalnego idealizmu. Ale Adorno niespodziewanie idzie o wiele dalej: mówi, że w systemie idealistycznym zwierzęta praktycznie odgrywają tę samą rolę, co Żydzi w systemie faszystowskim. Zwierzęta byłyby Żydami idealistów, którzy nie byliby niczym więcej niż wirtualnymi faszystami. I taki faszyzm zaczyna się za każdym razem, gdy obraża się zwierzę, nawet zwierzę w człowieku. Autentyczny idealizm polega na obrażaniu zwierzęcia w człowieku lub traktowaniu człowieka jak zwierzę. Adorno dwukrotnie odwołuje się do idei zniewagi. Nie jest to po prostu agresja werbalna, ale agresja polegająca na poniżaniu, obrzydzaniu, dewaluacji kogoś, podważaniu jego godności. Nie obraża się czegoś, lecz kogoś. Adorno nie posunął się nawet do stwierdzenia, że idealista obraża zwierzę, ale że obraża materialistę lub obraża człowieka, nazywając go zwierzęciem, co oznacza, iż „zwierzę” jest zniewagą. [A 103]

Gdyby jednak - przyjmuję - kierowany „odruchem współczucia dla istot cierpiących” Kant zgodził się na misję ratowania żuków, to, przypuścić należy z powodów już sugerowanych, zaangażowanie owo również musiałoby się kiedyś skończyć. $Z$ tego powodu dramatyczna dla Gombrowicza decyzja zaniechania ratowania konkretnego żuka nie byłaby dla niego większym problemem, ponieważ projektowana metafizyka moralności uwzględnia w sytuacji ostatecznej najdosłowniejszy prymat rozumu praktycznego nad odruchami empatycznymi. Tymczasem dla Gombrowicza ten właśnie moment ma znaczenie kluczowe. Trzeba mi więc wrócić do opowieści o żukach. Jest ona częścią obszerniejszego dziennikowego dyskursu na temat zwierząt, a także (w ogólności) relacji człowiek-natura, rozwijanego przez Gombrowicza niemal od pierwszych notatek z 1958 roku. Zaczyna się od spotkania z krowa - i zaskoczenia jej spojrzeniem, później mamy dyskusję z przyjaciółmi o jeździe konnej („zwierze nie rodzi się po to, aby dźwigać na sobie inne zwierze”, D-2 34), kolejne spotkanie $z$ krowami, będące pretekstem do krytyki polskiej tradycji opisów natury, a następnie polemiki z katolickim stosunkiem do zwierząt („Katolicyzm zlekceważył wszelkie stworzenie, poza człowiekiem. [...] Ból człowieczy ma dla katolika sens - podlega zbawieniu - wszak człowiek ma wolną wolę, więc to kara za grzechy, wszak życie przyszłe wynagrodzi najściślej krzywdy tego życia. Ale koń? Robak? O nich zapomniano. To cierpienie jest pozbawione sprawiedliwości nagi fakt ziejący absolutem rozpaczy. [...] Niech cierpią! [...] Przecież nie mają duszy", D-2 37), w końcu czytamy o przyznaniu się do obsesyjnych myśli o cierpiącej musze i o bólu w ogólności („Ból staje się dla mnie punktem wyjściowym egzystencji [...]" - stwierdza Gombrowicz 〈D-2 39〉). Po krótkiej przerwie temat wraca w formie mocnej historii o postrzelonym charcie, Stepie, i z dylematem związanym z tą sy- 
tuacją: czy skrócić męczarnie konającemu psu? Po czym wreszcie następuje opowieść o żukach na plaży.

Jeszcze przez chwilę pójdę tropami kafkowskimi, ponieważ względnie łatwo zauważyć, że już samo zaszycie się między wydmami ma w sobie coś z Kafki ${ }^{53}$. Ascetyczna, pustynna sceneria, odosobnienie - to przecież ten klimat. „Zdarzyło mi się wczoraj..." (D-2 52), zaczyna Gombrowicz. To z kolei jego ulubiona figura incipitowa, zwiastująca wejście w inny, czasem najdosłowniej niesamowity wymiar w sensie freudowskim, ale też i kafkowskim. U autora Zamku byłby to zdeformowany, nieprzyjemny „przedświat” ${ }^{44}$, mający wiele wspólnego także z tym, co dzieje się w powieściach Gombrowicza, kiedy gładką powierzchnię porządku kulturowego naruszają jakieś zakłócenia: zerwanie komunikacji, dewiacyjne tożsamości, perwersyjne intrygi. Wybór żuków jako istot cierpiących też jest decyzją szczególną, i to nie tylko dlatego, że Kafka miał upodobanie do kontekstu entomologicznego. Można odnieść wrażenie, iż Gombrowiczowi blisko do intuicji rozpoznanych przez badaczy, którzy zajmują się insektami w ramach animal studies - i te okoliczności mają, jak się wydaje, niebagatelne znaczenie dla rozpisanej przez Gombrowicza kwestii ${ }^{55}$. Pod jedną nazwą kryje się ujednolicenie ogromnej złożoności gatunkowej, wobec której i Gombrowicz kapituluje („Żuki jakieś - nie wiem, jak je nazwać [...]”, D-2 52). Relacja ludzi wobec owadów jest osobliwa, przyjmuje się bowiem milcząco ich całkowitą odrębność - to dystans większy niż wobec innych zwierząt, bo ludzi i owady dzieli coś głębszego od różnicy. Insekty to w perspektywie antropocentrycznej jeszcze mniej niż zwierzęta. Mimo nader częstych antropomorfizacji artystycznych nie jest nadużyciem mówienie wręcz o autentycznej kulturowej entomofobii, na którą składają się fantazmaty zagrażającej niepoliczalności i rozmnożenia - w tym sensie insekty stanowią zaprzeczenie pojedynczości istnienia, będącej przywilejem zwierząt udomowionych ${ }^{56}$. Dlatego insekty sa wyjęte spod prawa, przemoc wobec nich nie jest ani karana, ani nawet wattpliwa moralnie. Być może właśnie $z$ tych powodów Gombrowicz stawiając kwestię bólu oraz ratowania konkretnego żuka, wydobywa go $\mathrm{z}$ fantazmatu niepoliczalności i tym samym uruchamia Kafkowska problematykę: decyzji, niemożności działania, odpowiedzialności i winy, a także względności tego, co etyczne i nieetyczne.

Taki kontekst, kontekst moralności, powinności, zobowiązania oraz wrażliwości, Gombrowicz przywołuje już w pierwszych słowach przez nawiązanie do wcześniejszej opowieści o psie z estancji. Opowieść ta podejmowała podobna problematykę: sytuacji granicznej, relacji człowiek-zwierzę, życie-śmierć etc. Gombrowicz

Byłoby to przeciwstawienie zwierząt zedypalizowanych, a więc jednostkowych, sentymentalizowanych, antropomorfizowanych i stymulujących ludzki narcyzm, zwierzętom demonicznym, właściwym sforom i afektom, które tworzą mnogość, jak powiedzieliby G. De le u ze i F. Gu a ttari (Tysiąc plateau. Red. merytor. i język. J. B e d n a r ek. Przedm. M. Her e r. Warszawa 2015, s. 291).

Dla J.-P. Salga s a (Gombrowicz lub ateizm integralny. Przeł. J. M. Kł oczows ki. Warszawa 2004, s. 112) ma ten fragment „wymiar małego opowiadania kafkowskiego”.

Zob. W. B e nj a m i n, Franz Kafka. Z okazji dziesiątej rocznicy jego śmierci. W zb.: Nienasycenie, s. 45, 52 (przeł. A. Lipszyc).

Zob. M. Żółkoś, Mikro-formy i makro-lęki. Owady jako wyzwanie dla animal studies. W zb.: Zwierzęta i ich ludzie. Zmierzch antropocentrycznego paradygmatu. Red. A. B a r c z, D. Ła go dzZwierzętai ich ludzie. Zmierzch a 
sugeruje, że tylko pisanie stanowiłoby ambiwalentne remedium na indywidualnie doświadczaną rozterkę moralną: „Mógłbym to powiedzieć. Mogę też dręczyć się tym - lub nie dręczyć - to właściwie ode mnie zależy” (D-2 52). Tym razem narracja rozwija się spokojniej. Zaczyna się od żuka przewróconego przez wiatr i najwyraźniej konającego. Gombrowicz konstatuje swoją absolutną inność od owada („Ja, olbrzym, niedostępny mu swoim ogromem, który to ogrom czynił mnie dla niego nieobecnym", D-2 52), ale po niedługim namyśle ratuje go. Po czym widzi następnego w takich samych opałach - i jego też ratuje. Uruchamia mu się imperatyw omalże kategoryczny: ,jeśli już zacząłem to ratowanie, nie miałem prawa zatrzymać się w dowolnym miejscu" (D-2 53). Gombrowicz ratuje kilkanaście, może kilkadziesiąt kolejnych, szybko jednak uzmysławia sobie, że w imię takiej samej, z ducha kantowskiej moralności, kiedyś musi (może?) się zatrzymać, problem polega wszakże na tym, żeby „była jakaś g r a n i c a, coś co mogłoby upoważnić [...] do zaprzestania [...]” (D-2 53). Ale takiej granicy na horyzoncie nie było. Ta scena nie ma świadków. Jest tak najpewniej z powodów, które sugerowała autorka wstępu do amerykańskiego wydania Ferdydurki, Susan Sontag: „gdy chodzi o oglądanie cudzego cierpienia, żadnego "my" nie wolno uznawać za oczywiste" ${ }^{7}$. Gombrowicz zostaje sam ze soba, jest odpowiedzialny wyłącznie przed sobą, skazany na podjęcie decyzji na własny koszt, ze wszystkimi tego konsekwencjami. Dylemat w skrajnej postaci brzmiał jednak tak:

więc musi nadejść moment, w którym powiem „dość” i musi nastąić ten pierwszy żuk nie uratowany. Który? Który? Który? Co chwila mówiłem sobie „ten” - i ratowałem go nie mogąc się zdobyć na tę straszną, nikczemną prawie arbitralność - bo i dlaczego ten, dlaczego ten? [D-2 53]

W końcu Gombrowicz reaguje niespodziewanym, gładkim zawieszeniem w sobie empatii. Przyznaje się, iż poczuł obojętność i niechęć, wcześniej jeszcze wspomniał, iż osiągnął miejsce, w którym „człowieczeństwo musi wymiotować...” (D-2 52). Nie jest to przypadek ani jakaś prowokacyjna manifestacja nihilizmu, ale najbardziej bolesnej bezradności, co potwierdza Sontag piszaca, że kiedy człowiek nie może nic zrobić w sytuacji dojmującego współczucia, „to ogarnia go nuda, cynizm, apatia” 58 .

Ma się rozumieć, nie bezradność - co najczęściej sugerowali dotychczasowi komentatorzy i komentatorki - jest tu czymś najdotkliwszym, ale całkiem przeciwnie: konieczność podjęcia decyzji, decyzji, k tó r e go żuka uratować jako o s tatniego, którego zaś skazać na agonię i śmierć. Wydaje się jasne, iż wybór jest konieczny, lecz zarazem w tym sensie niemożliwy, że każde rozwiązanie będzie problematyczne ${ }^{59}$. Wymiar etyczny tej historii uruchamia się właśnie na płaszczyź-

S. S o n tag, Widok cudzego cierpienia. Przeł. S. Ma gala. Kraków 2016, s. 13.

Ibidem, s. 121. Warto dodać, że podobne emocje wzbudzały w Gombrowiczu same myśli o uporczywej odrębności zwierząt, aczkolwiek wpisywał je w kontekst najważniejszych swoich zaciekawień:

„Mnie ku tym dołom, ku konfrontacji z koniem, żukiem, rośliną, pcha moje dążenie do "nawiązania Z niższością". [...]

Ale - jakaś niechęć... Przyznam się - to mnie nudzi. Nie chce mi się o tym myśleć. I nie lubię, prawie nie znoszę - wybierać się myśla poza królestwo ludzkie. [...]

Rozumieć naturę, oglądać ją, badać - to jedna sprawa. Ale gdy usiłuję podejść do niej, jak do czegoś zrównanego ze mną wspólnością życia, które nas obejmuje, gdy chcę być ze zwierzętami, z roślinami "na ty" - ogarnia mnie niechętna ospałość, tracę animusz, co prędzej wracam do mego ludzkiego domu i zamykam drzwi na klucz" (D-2 38).

Tylko Jarzębski (Literatura jakoforma istnienia, S 173) trafiał w punkt: „nie sposób podjąć 
nie lektury i narracja Gombrowicza w sposób oczywisty dotyka tematyki krytyki etycznej, podejmującej kwestie wyborów moralnych, których dokonuja protagoniści literaccy i czytelnicy/czytelniczki w praktykach lekturowych, a także wrażliwości, empatii i powinności wobec rzeczywistości pozatekstowej ${ }^{60}$. Czytelnik/czytelniczka niejako tworzą inscenizację aktu problematycznej decyzji na własny koszt ze wszystkimi tego konsekwencjami. Odgrywaja powtórzenie, które nie jest powtórzeniem $^{61}$. Dochodzac do momentu decyzji dziennikowego Gombrowicza, empatycznie przeżywają ów wybór ostatniego uratowanego żuka oraz myśli o kolejnym żuku, który nie został uratowany. Czytelnik/czytelniczka mogą przystępować do lektury z konkretnym bagażem przeświadczeń moralnych na temat zobowiązań etycznych, różnic między człowiekiem a zwierzęciem etc. Opowiastka ta ma więc władzę, żeby zdruzgotać kościec moralny czytelnika/czytelniczki, jest zdolna jednak uruchomić przeżycie etyczne: uwrażliwienie na ból, refleksję nad zobowiązaniami moralnymi, wątpliwości w sprawie istnienia uniwersalnej etyki, sympatię wobec zwierząt itd. Ale to nie koniec. Decyzja staje się najbardziej dotkliwa, kiedy przebudzoną empatię wspiera wyobraźnia. To ważne: porządek fikcji utrudnia decyzję, lecz czyni ja tym samym rzeczywistym wyzwaniem, prawdziwym wyborem, przydaje największego znaczenia lekturze etycznej. Fikcyjny namysł pozwala na zniuansowanie kwestii: ta konkretna istota, ten a nie tamten. Wyobraźnia pracuje dalej i podsyła hipotetyczne scenariusze nieziszczonej, niemożliwej egzystencji, zapytuje: jakiej żuk był płci (czy one w ogóle mają płeć?), czy był młody czy stary, jakie dotąd było jego życie (szczęśliwe czy pełne cierpienia), a jakie byłoby, gdyby nie powzięta decyzja (niewykluczone, iż tylko pomyślne). Nie jest też tak, że jakaś nieokreślona przyszłość może dać potwierdzenie. Nic podobnego. Przyniesie wzrastająca niepewność co do słuszności podjętego wyboru. Decyzje są brzemienne w skutki i konsekwencje, te zaś pozostają określone. To już kwestia realnej odpowiedzialności za dokonany wybór. Widzimy tu następne argumenty, że potencjał afektywny opowieści sentymentalnej charakteryzuje się większą skutecznością perswazyjną i edukacyjną od normatywnego dyskursu na temat moralności ${ }^{62}$.

Wydaje mi się, iż Gombrowicz staje - i stawia czytelników/czytelniczki - przed aporią, iście dekonstrukcyjna nierozstrzygalnością niesprowadzająca bynajmniej wszystkiego, jak utrzymuje doksa powszechna niezaznajomiona dokładniej z dekonstrukcją $^{63}$, do horyzontu wyrafinowanych tekstualnych igraszek, nieskazująca

suwerennej decyzji o czyimś "być albo nie być" i z pełną świadomością zaprzestać na którymś konkretnym żuczku akcji ratunkowej”.

Zob. J. Hilli s Mille r, Czytanie dokonujace odczytania. W zb.: Dekonstrukcja w badaniach literackich. Red. R. Ny c z. Gdańsk 2000, s. 126 (przeł. P. W a w r zy s zk o). - N. Ca r ro 11, Sztuka a krytyka etyczna. Przeglad najnowszych kierunków badań. „Teksty Drugie” 2002, nr 1/2 (przeł. J. Zi ęba). Zob. też A. Burzyńska, Dekonstrukcja, polityka i performatyka. Kraków 2013, s. 37-125.

61 Zob. D. Attridge, Jednostkowość literatury. Przeł. P. M oś ci c ki. Kraków 2007, s. 130.

62 Hillis Miller (Czytanie dokonujace odczytania, s. 126-127) podkreśla osobliwość związów narracyjności i konkretności (w sensie: nieabstrakcyjności) w dyskursie etycznym. Nawiązując do Kanta historii o człowieku składającym obietnicę, wyciągnie dekonstrukcjonistyczny wniosek: bez opowieści nie ma teorii etyki, ale opowieść kwestionuje prawo moralne.

63 Nie tylko zreszta potoczna, bo np. R. Braid otti (Postludzkie, arcyludzkie. Ku nowej ontologii procesualnej. Przeł. J. Mali ń ski. Machina Myśli” 2018, s. 4. Na stronie: http://machinamy- 
na polityczną impotencję i niezamykającą możliwości wyboru i, w ogólności, refleksji etycznej, ale ją tak naprawdę otwierającą. Derrida w następujący sposób uzasadniał w książce Aporias swoje przywiązanie do tej kategorii:

greckie słowo „aporia” [...] wybrałem dawno temu [...], nie wiedząc wcale, dokąd zmierzam poza tym, że wiedziałem, iż w tym słowie chodzi o „nie wiem, dokąd iść”. Musiało być w nim coś z nieprzekraczania, braku przejścia, a raczej doświadczenia braku przejścia, doświadczenia tego, co się w tym braku przejścia wydarza i co fascynuje, paraliżując nas w tym rozdzieleniu w sposób, który niekoniecznie jest negatywny: przed drzwiami, na progu, na granicy, na linii lub po prostu na krawędzi albo na skraju tego, co inne jako takie. Byłaby to kwestia tego, co w sumie zdaje się blokować nam drogę lub zatrzymywać nas w miejscu, w którym nie jest już możliwe stworzenie problemu, żadnego projektu bądź projekcji, tj. w miejscu, gdzie każdy problem czy problematyka staje się niemożliwa i gdzie jesteśmy wystawieni, całkiem bezbronni, bez problemu i bez żadnej protezy, żadnego możliwego zastępstwa, osobliwie wystawieni w naszej absolutnej i absolutnie nagiej pojedynczości ${ }^{64}$.

Jest to pojęcie prawdziwie graniczne w tym sensie, iż stawia w obliczu transgresji, na krawędzi, w sytuacji przejścia i wyboru, w sytuacji najdosłowniej bezwyjściowej, w sytuacji totalnej niewiedzy, którą drogę wybrać. Bez zabezpieczeń ontologicznych i dyskursywnych, bez jakichkolwiek presupozycji gwarantujacych powodzenie. Tu nie ma żadnego alibi w postaci uprzedniej wiedzy, którą można by się posłużyć niczym poradnikiem albo kodeksem. A jednak sytuacja podobnego paraliżu to dla Derridy okoliczność niekoniecznie beznadziejna. On nie widzi już problemu - w sensie przede wszystkim etymologicznym. „Problèma” znaczyć może zarówno „projekcję", jak i „protekcję”, a zatem i postawienie przed czymś - projektem czy zadaniem, i ochronę. „Każda granica jest problematyczna w tych dwóch sensach”65 - powiada w związku z tym. Z kolei w pracy Darować śmierć (Donner la mort) wykładał:

Taka jest aporia odpowiedzialności: w samym procesie tworzenia pojęcia odpowiedzialności ryzykujemy niemożność jego akceptacji. Odpowiedzialność bowiem (nie odważymy się już mówić o „powszechnym pojęciu odpowiedzialności”) wymaga od nas dwóch sprzecznych postaw. $Z$ jednej strony, żąda wytłumaczenia, ogólnego odpowiadania-za-siebie w ogóle i wobec ogółu. $Z$ drugiej strony, pragnie wyjątkowości, absolutnej jednostkowości, a więc milczenia, tajemnicy i niepowtarzalności ${ }^{66}$.

To sytuacja Abrahama, który ofiarowuje Bogu swojego syna Izaaka. Tytułowe darowanie śmierci oznacza pozbawienie życia w imię miłości, ale za cenę zdrady. Moralność łączy się z tu z niemoralnością, odpowiedzialność z nieodpowiedzialnością. I przekroczeniem granic rozumu: „Chwila decyzji jest szaleństwem” - w związ-

sli.org/postludzkie-arcyludzkie-ku-nowej-ontologii-procesualnej-2/ (data dostępu: 21 III 2020〉) pomawia Derridę o „celebrację niedecydowalności”.

J. De rrid a, Aporias. Transl. T. D u to it. Stanford, Calif., 1993, s. 12. Przy innej okazji francuski filozof stwierdził: „Decyzja może jedynie zaistnieć w przestrzeni przekraczającej obliczalny program, który zniszczyłby wszelką odpowiedzialność, przekształcając ją w programowalny skutek określonych przyczyn. Nie byłoby odpowiedzialności moralnej ani politycznej bez tej próby i tego przejścia drogą nierozstrzygalności. Nawet jeśli decyzja wydaje się podjęta w sekundę, niepoprzedzona żadnymi rozważaniami, to jest ona ustrukturowana przez to doświadczenie i eksperyment nierozstrzygalności” (J. Derrida, Afterword: Toward an Ethic of Discussion. W: Limited Inc. Ed. G. G r a ff. Transl. S. W e be r. Evanston, Ill., 1988, s. 116). Derrida, Aporias, s. 12.

66 J. De rri d a, Darować śmierć. Komu darować. (Wiedzieć, by Nie Wiedzieć). W zb.: Czytanie Derridy. Red. B. Małczyń ski, R. Włodarczyk. Wrocław 2005, s. 76 (przeł. K. Lis zka, M. Pawlikowska). 
ku z tym za Kierkegaardem powiada Derrida ${ }^{67}$. Nieco dalej czytamy następujące słowa:

Nie mogę odpowiedzieć na czyjeś wezwanie, prośbę, zobowiązanie czy nawet miłość, bez poświęcenia mu kogoś innego, innych innych. Ka żdy inny jest całkiem inny 〈toutautre est toutautre〉. Pojęcia inności [l'altérité] i jednostkowości konstytuują zarówno pojęcie zobowiązania, jak i odpowiedzialności. W rezultacie pojęcia odpowiedzialności, decyzji czy zobowiązania skazane są a priori na paradoks, skandal, aporię. Paradoks, skandal i aporia same w sobie nie są niczym innym, jak ofiarą, obnażeniem myślenia konceptualnego w jego granicach, w jego śmierci i skończoności ${ }^{68}$.

\section{W rozmowie $z$ Elisabeth Roudinesco autor Widm Marksa powiedział:}

Ale tam gdzie przychodzi ten (to), kto (co) pozostaje do nadejścia, jestem narażony, powołany do bycia wolnym i do decydowania według miary, której nie mogę przewidzieć, z góry określać, prognozować. [...] Stan decyzji 〈décision〉 (decyzji, że trzeba i że trzeba wszędzie robić założenia) to doświadczenie owej nierozstrzygalności 〈indécidable〉, o której mówiłem właśnie pod postacią tego, „kto (co) nadchodzi”. Jeśli wiem, co trzeba zadecydować, nie decyduję. Między wiedzą a decyzją wymagany jest skok, nawet jeśli przed podjęciem decyzji trzeba wiedzieć najwięcej i najlepiej, jak to możliwe ${ }^{69}$.

W takim kontekście Derrida myśli o „postdekonstruktywistycznej cnocie”, oznaczającej swoista „odpowiedzialność p r zed moją wolnością"70. Cnota ta jest szczególnym, paradoksalnym rodzajem odpowiedzialności w heteronomii, wolności bez autonomii i z otwarciem na to, co absolutnie nieprzewidywalne. Ten kto - lub co - nadchodzi, nie musi być innym człowiekiem, bliskim albo bliźnim, może to być „życie”, „widmo” w formie zwierzęcej czy boskiej (niebędące „Zwierzęciem” lub „Bogiem") bądź istota poza binarnymi, heteroseksualnymi rozróżnieniami.

Wydaje się, że podobną konfrontację inscenizuje Gombrowicz. Ból - powtarza raz po raz - tak dla zwierzęcia, jak i dla człowieka pozostaje czymś niedostępnym, wykluczającym możliwość interpretacji, co znaczy tu: usensownienia albo sublimacji (przykład stanowi chrześcijańskie rozumienie bólu jako czynnika duchowo uszlachetniającego, z którym Gombrowicz polemizował m.in. w opowieści o Stepie, stwierdzając rzecz zastanawiająca: „Jedyne, co nas łączyło z tym stworzeniem, to zrozumienie bólu - ten smak znaliśmy" $\left\langle\right.$ D-2 46/) ${ }^{71}$. To, że chodzi tu o zwierzę, że chodzi tu tylko o insekta, nie jest ważne, ponieważ bólu człowieka i zwierzęcia Gombrowicz nie chce różnicować. Tu wybór pada na „robaki”, ale poprzednia opowieść dotyczyła konkretnego charta, mającego imię i wyjątkową relację $z$ właścicielem. Gombrowicz bohaterami podobnej historii nie zdecydował się uczynić swoich zwierzaków: Psinę albo kota Autostopa, z którymi pokazywał się na zdjęciach

Ibidem, s. 79. Warto wspomnieć, że z tych słów J. D e r r i d a (Cogito i historia szaleństwa. W: Pismo i różnica. Przeł. K. Kło siński. Warszawa 2004, s. 57) uczynił motto w słynnej polemice z M. Foucault dotyczącej Historii szaleństwa $w$ dobie klasycyzmu.

69 J. Derrida, E. Roudine s c o, Z czego jutro... Dialog. Przeł. W. Szydłowska. Warszawa 2016, s. 79.

70 Ibidem, s. 77.

71 Wedle mojej wiedzy nikt dotąd tego nie zrobił, ale możliwość interpretacji kategorii bólu u Gombrowicza za pomocą Lacanowskiego terminu „Realne” jest oczywista. Zwłaszcza że J. La c a n (The Seminar. Cz. 7: The Ethics of Psychoanalysis 1959-1960. Ed. J.-A. Miller. Transl. D. Porter. New York - London 1997, s. 20) łączy nakaz moralny z Realnym. Kategorię tę - rozumianą jako to, co bezforemne, przygodne, asymboliczne, pozaludzkie, nieznośne, a co zawsze wraca na to samo miejsce - zastosowałem do opisu, Niedojrzałości” (zob. Bi ele c k i, Widma nowoczesności, s. 44). 
(mimo że przedstawiając filozofię Kanta, nie wahał się uczynić przykładem hipotetyczne uśmiercenie swojej matki). Bez wątpienia byłaby to szczególna komplikacja, która pomogłaby uniknąc impasu sugerowanego przez Derridę, kiedy to podnosząc par excellence filozoficzny problem bycia widzianym nago pod prysznicem przez swoja kotkę, kładł nacisk na to, że jest to jego kotka, prawdziwa, konkretna, niepowtarzalna, nie będąca figura kota w ogólności albo kulturową alegorią, ani nieprzynależąca do Kafkowskiej zoopoetyki, ani nie pozwalająca się wpisać w filozoficzne, homogenizujące tendencje, które ujmują zwierzęta w kategoriach ogólnych, niwelujących ich różnorodność (A 6, 32, 47-48, 59) ${ }^{72}$.

„Nie istnieje coś takiego jak zwierzę w ogólnej liczbie pojedynczej, odseparowane od człowieka przez jedną niepodzielną granice” (A 47) - przekonuje Derrida. W jakiejś mierze z uogólniającej pułapki, w jaką wpędziła go metafora entomologiczna, Gombrowicz wywikłał się w opowieści o Stepie, gdzie decyzję podejmuje właściciel. Tylko on może to zrobić i wybrać życie zamiast śmierci, mając nadzieję, iż pies wydobrzeje - aczkolwiek Gombrowicz sugeruje, że czyni to w imię pobudek narcystycznych i egoistycznych, o czym czytamy w Heglowskiej retoryce Pana i Niewolnika, oraz walki o uwielbienie lub uznanie. Wychodzi raczej na to, iż w żadnej ze wspomnianych historii - o Stepie, o krowie, nawet o żukach, jeśli ma się na myśli, że najbardziej problematyczny i dramatyczny moment to ten zwiazany z koniecznością wyboru między konkretnymi żukami, a także inne przygodne uwagi (np. w rekonstrukcji polemiki Sørena Kierkegaarda z Georgiem Wilhelmem Heglem ${ }^{73}$ ) - Gombrowicz nie wpisuje się w tradycję alegoryczną, w której zwierzęta występują w roli „uosobionych abstrakcji” ${ }^{74}$, stanowiących w istocie figury cech ludzkich.

Gdyby chcieć nakreślić jakieś najbardziej prowizoryczne ramy etyki, jaką projektowałby tutaj Gombrowicz, to warto na wstępie zwrócić uwagę na kolejność zdarzeń. Dziennikowy Gombrowicz na początku jest kimś, kto po prostu leży na plaży, kto tym samym jakby usiłuje się zdystansować od innych i raczej nie ma zamiaru przeżywać rozterek etycznych. Pojawia się jednak cierpiący żuk, po nim następne. Najpierw jest więc przeczucie przejmującego, nieznośnego bólu, dopiero potem przychodzi odruch moralny. Uwrażliwienie na ból stanowi coś, co wzywa i prowokuje. Afektywne doznanie empatii, zaświadczenie czyjegoś bólu, są zatem czymś uprzednim względem działania i namysłu moralnego - i dopiero ten mo-

72 Polski pisarz antycypuje wiele $z$ sugestii francuskiego filozofa. U Gombrowicza zwierzęta cierpią, umierają i patrzą. Scena ukazująca Derridę zakłopotanego spojrzeniem kotki przywodzi na myśl Gombrowicza skonfundowanego spojrzeniem krowy: „wstyd człowieczy wobec zwierzeccia. Pozwoliłem, żeby ona spojrzała na mnie i zobaczyła mnie - to nas zrównało - wskutek tego stałem się także zwierzęciem [...]” (D-2 34). Nie jest to sprawa błaha, bo „spojrzenie [...] widzące” (D-2 36) zwierzęcia oznacza, po pierwsze, uświadomienie sobie nagości (a więc przejście od zwierzęcości), po drugie, pozbawienie człowieka uprzywilejowanego zmysłu, przynajmniej we wzrokocentrycznej filozofii. Na ten temat pisze M. J a y (Downcast Eyes. The Denigration of Vision in Twentieth-Century French Thought. Berkeley - Los Angeles 1994). „Stawanie się zwierzęciem” u Gombrowicza zauważył G. Dele uze (Literatura i życie. W: Krytyka i klinika. Przeł. B. Banasiak, P. Pi eni ąż e k. Łódź 2016, s. 5).

73 Oto dwa $z$ argumentów przeciwko uogólnieniom Hegla: „Ale ten abstrakcyjny koń to jest właśnie koń, który nigdy nie istniał, w życiu mamy tylko tego, czy owego, zawsze konkretnego konia” (W 277); „Ale taki koń nigdy nie istniał, gdyż każdy konkretny koń ma swoją barwę” (PW 83).

74 D. L. Say e r s, O pisaniu i czytaniu utworów alegorycznych. W zb.: Alegoria. Red. J. A b r a m o wska. Gdańsk 2003, s. 22 (przeł. P. Graff). 
ment czyni Gombrowicza podmiotem etycznym. Doświadczenie Innego poprzedza tu etykę, poprzedza zobowiązanie, poprzedza decyzję. Zobowiązanie polega wobec tego na przejściu od podmiotowej autonomii do heteronomii doświadczenia Innego. Inny pojawia się jako wyzwanie i zobowiązanie: w imię solidarności w bólu. Gombrowicza zatem - jak Benthama, a w odróżnieniu od wielu, wielu filozofów - nie interesuje u zwierząt brak świadomości czy ich niezdolność do komunikacji, ale przynajmniej nie są to wattpliwości najważniejsze; to zaś, co prawdziwie niewątpliwe i przez to zajmujące, stanowi wspólnota w doświadczaniu bólu. To jedyna podstawa, jaka potrafię dostrzec w zarysowanej sytuacji.

Gombrowicz nie tworzy żadnej hipostazy, żadnego imperatywu, żadnego uniwersalnego nakazu. Żadnego prawa moralnego obligującego do bezwarunkowej pomocy. Nie tworzy teoretycznej abstrakcji w Innym, Inności czy czegoś w tym stylu - choć zdarzało mu się posługiwać podobnymi kategoriami. Nie zostaje ustanowiony nawet jakiś podmiot etyczny, poprzedzający decyzję, raczej to przygodna sytuacja wymusza decyzje i przez to kreuje performatywnie podmiot etyczny. Wszystko to bardzo zgadza się z Gombrowiczowską filozofią interakcyjności. Nie ma tu autonomicznego podmiotu Kanta, jest podmiot heteronomiczny, uwarunkowany sytuacyjnie i relacyjnie - doświadczeniem kogoś bezradnego, bezbronnego, cierpiącego, kto nawet nie prosi o pomoc. Prawdopodobnie to przynosi dodatkowe wyjaśnienie, dlaczego bohaterami historyjki stały się żuki, będące - jak człowiek czymś żywym, ale jednocześnie czymś maksymalnie odległym, jakąś elementarną, prymitywną formą istnienia (może czymś na kształt greckiego dzoē, czyli nagiego życia właściwego wszystkim bytom ożywionym), zredukowaną dodatkowo do traumatycznego doznania, które pozostaje jeszcze czymś przez Gombrowicza domniemanym, ale mimo to stanowi motywację do działania. Wszystko to potrzebne było Gombrowiczowi, aby sformułować minimalną płaszczyznę relacji. Bez możliwości czy wręcz pokusy jakiejkolwiek identyfikacji - pozytywnej w rodzaju utożsamienia albo negatywnej w postaci odróżnienia ${ }^{75}$. Bez komunikacji, poznania, zrozumienia. Bez ewentualności asymilacji, wspólnoty i sentymentalizmu. Nawet bez-jakkolwiek to zabrzmi - poszanowania.

Dlatego język Kantowski: powinności, obowiązków, imperatywów, ale też uniwersalnego humanizmu, zupełnie nie przystaje do tej sytuacji. Impuls afektywny musi się wydawać bardziej wiarygodny i autentyczny, ponieważ działanie wynikłe z potrzeby jest więcej warte niż sprowokowane zobowiązaniem. Efektem będzie myślenie o etyce, której nie da się wydedukować $\mathrm{z}$ czegoś uprzedniego względem sytuacji wyboru, niemającej żadnego ugruntowania poza wrażliwością i empatią powodowaną świadomością wspólnoty, która jest podatna na ból i cierpienie. Tak jakby Gombrowicz intuicyjnie antycypował Derridy gre słów w tytule L'Animal que donc je suis między dwoma znaczeniami ,je suis" (a także z Kartezjańską formuła „myślę, więc jestem”) - ,jestem” i „podążam”; grę, która miała sugerować pierwszeństwo i zarazem bycie doświadczeniem formacyjnym zwierzęcia (sc. natury) dla człowieka (A 3). Tymczasem część gombrowiczologów powiela tradycyjne uprzedzenia filozoficzne i na założeniu nieposiadania przez zwierzęta świadomości i ich niezdol- 
ności do komunikacji opiera przeświadczenia o tym, że Gombrowicz stabilizuje opozycję między ludźmi a zwierzętami ${ }^{76}$. Jest to mniemanie błędne nie tylko dlatego, iż łatwo o dowody, że zwierzęta mają świadomość, złożone systemy komunikacji, formy organizacji symbolicznej i struktury społeczne ${ }^{77}$, ani dlatego nawet, że właśnie komunikację ludzką Gombrowicz przedstawia w swoich tekstach jako jedno wielkie nieporozumienie albo coś właściwie niemożliwego - to m.in. zakładałem, pisząc o antyhermeneutyce i hermeneutyce niemożliwej, ale przede wszystkim $z$ tego powodu, iż Gombrowicz wcale nie żyruje takiej „prostej i opozycyjnej granicy między Człowiekiem a Zwierzęciem" także w swoim dyskursie literacko-filozoficznym ${ }^{78}$.

Gombrowiczolodzy omawiający przygodę dziennikowego Gombrowicza na plaży nie zwracali uwagi - poza jednym wyjątkiem - na zamieszczony zaraz na następnej stronicy komentarz do całego zajścia. Nie jest on ani szczególnie czytelny, ani konkluzywny. Ale już chyba wiadomo, że nie może być inny. Gombrowicz od początku tego fragmentu wykonuje niejasne gesty, lecz trudno nie widzieć w tym przejawów najwyższego zakłopotania. Siedzi w cukierni na „rambli”, trwa dancing i samba, i w tej atmosferze Gombrowicz usiłuje się rozluźnić po traumie plażowej. Na darmo jednak. Myśli są obsesyjne, jak zwykle - dają się zanotować wyłącznie w cudzysłowie i sprowadzają rzecz do „kompromitacji”, „nikczemności” i „bezsilności”. Wpisuje je Gombrowicz w dyskurs często u niego się pojawiający o „kiwaniu na diabła”, zaraz wszakże nadmienia, że nie jest to stylizacja na jakąś zamierzchła demonologie, ale całkiem przeciwnie - przynależy do przyszłości. Gombrowicz przyznaje się do porażki, wspomina o abdykacji ze sprawiedliwości, moralności i ludzkości, ponieważ nie mógł sprostać ilości:

Zob. W. B o le c k i, „Jak zachować się wobec krowy?” (Wstęp do bestiarium Witolda Gombrowicza). Wstęp w: W. G o m b r ow i c z, Bestiarium. Wybór, układ W. B ole c ki. Kraków 2004, s. 15-16. M. P. M a rk ow s ki, Czarny nurt. Gombrowicz, świat, literatura. Kraków 2004, s. 123, przypis 85. Zob. J. Bednarek, Życie, które mówi. Nowoczesna wspólnota i zwierzęta. Warszawa 2017, s. 120-135.

78 Derrida, Roudines c o, op. cit., s. 92. Parę dowodów na tę nieufność Gombrowicza. Wczesny tekst $Z$ diariusza prywatnego Hieronima Poniżalskiego, $\mathrm{z}$ bohaterem, któremu odrzucono tekst Człowiek-zwierze (P 19). W autokomentarzu Postawa nowych autorów. Choromański, Gombrowicz, Rudnicki zacytowane są słowa Esquirola o człowieku, będącym „machiną z natury już bezrozumną, łączącą w sobie właściwości zwierzęcia i poety [...]" (P 135). To skojarzenie zwierzęcości i poezji dochodzi do głosu także w metaforyce krytycznoliterackiej, np. w recenzjach twórczości E. Szemplińskiej (P 139-141). Później jest nie inaczej. W kontekście traumy obozu koncentracyjnego G o m b r ow i c z rzuca uwagę: „Środki naszego obcowania z ludźmi są dotąd znikome. Straszna samotność zwierząt, które zaledwie się porozumiewają... Ale człowiek? Niezbyt jeszcze oddaliliśmy się od zwierząt i pojęcia nie mamy, czym może być wdarcie się drugiego człowieka w naszą jaźń zamkniętą" (D-1 278). Pisarz we wspomnianej polemice z tradycją hippiczną człowieka nazywa zwierzęciem. Żeby była jasność: Gombrowiczowi nie idzie o zlikwidowanie granicy między ludźmi a zwierzętami, ale - myślę, że podobnie jak Derridzie (D e r r id a, Ro u d i n e s c o, op. cit., s. 96-97) o multiplikację różnic zacierających czystość tego nazbyt prostego podziału. Gombrowicz stwierdza np. prowokująco: „między człowiekiem a człowiekiem powstają różnice stokroć większe niż w całym świecie zwierzęcym" (D-2 80). Z kolei w polemice dotyczącej traktowania zwierząt przez chrześcijan używa przewrotnie argumentu religijnego - skoro człowieka i konia tworzył Bóg, to wiosek $\mathrm{z}$ tego rozumowania musi być następujący: „Tak tedy koń z człowiekiem zlewają się w harmonii tego prapoczątku. Kontrast między nimi jest uleczalny” (D-2 37). Zob. M. P a ń c za k, „Antynaturalizm” Gombrowicza, albo po co ekokrytyce pamięć o nowoczesności. „Przestrzenie Teorii” 2017, $\mathrm{nr} 28$. 
Przepraszam! Ależ to równa się stwierdzeniu, że moralność jest niemożliwa. Ni mnie ni więcej. Gdyż moralność musi być ta sama w stosunku do wszystkich, w przeciwnym razie staje się niesprawiedliwością, a więc niemoralna. Ale ta ilość, ten ogrom ilości, skoncentrował się na jednym jedynym robaku, którego już nie wybawiłem - na którym przerwałem. Dlaczego on akurat, a nie inny? Dlaczego ten jeden musi płacić za to, że ich miliony? [D-2 54-55]

Podsumowuje kwestię tak oto:

W miarę rozmyślania nad tym [tj. nad wątpliwościami związanymi z okazywaniem litości] moje samopoczucie staje się jakieś dziwne; mam wrażenie jak gdybym dysponował tylko moralnością ograniczoną... i fragmentaryczną... i arbitralną... i niesprawiedliwą... moralnością, która (nie wiem, czy to jasne) jest $z$ natury swojej nie ciagła, ale zi arn is ta. [D-2 55]

Forma zapisu nie jest, oczywiście, przypadkowa, a wykładnik stylistyczny w postaci wyliczenia, zawieszanej i rwanej składni zdaje się obrazować trudności, z jakimi wiąże się próba skodyfikowania wypracowywanej koncepcji moralności. Trzeba to chyba rozumieć jako rezygnacje $z$ jakiejkolwiek kategoryczności i jako zaniechanie czy odroczenie wszelkiej konkluzywności. Na podobną trudność zwracał uwagę Derrida, zastanawiający się nad dyskursem negatywności - który przypomina $n b$. teologię negatywną - w jaki wikła się myślenie o niemożliwym zobowiązaniu, i jak miałoby to myślenie znaleźć swoje afirmatywne przełożenie. Nieuchronność ta bierze się $z$ konieczności uniknięcia wszelkiej krzepiącej pozytywności: dobrego sumienia, subiektywnej pewności, a także wsparcia w postaci wiedzy albo teorii, ponieważ jako takie wykluczają się one $z$ sytuacją absolutnego ryzyka związanego $\mathrm{z}$ prawdziwa obietnica, $\mathrm{z}$ realnym zaangażowaniem i odpowiedzialna decy$z_{j a}{ }^{79}$. Użyte przez Gombrowicza kategorie, określające jego koncepcję moralności, sa zagadkowe. „Ograniczona”, „fragmentaryczna”? Zrozumiałe, że nie chodzi mu o konstatację „bankructwa uniwersalnej etyki” - to nazbyt oczywiste dla każdego, kto nie jest fundamentalistą moralnym czy fanatycznym kaznodzieją. Nie idzie tym bardziej o instrukcję w rodzaju: którego żuka uratować. Ani o uspokojenie, że wszystkie żuki (całego świata) nie sposób uratować ${ }^{80}$. Wręcz odwrotnie, żadne pocieszenie nie jest tu możliwe. Gombrowicz nie namawia do cynizmu, nie głosi niemożliwości empatii albo zarzucenia idei pomocy czy odpowiedzialności. Przeciwnie, decyzja o pomocy stanowi odruch, zobowiązanie do czegoś oczywistego. Na tym jednak oczywistości się kończą.

Gombrowicz nie daje recepty, ale inscenizuje same ogólne warunki i procedurę decyzji etycznej. Moralność „ziarnista”, „nieciagła” i „niesprawiedliwa”? ${ }^{81}$ Sądzę, że byłaby ona w dosłownym, opisowym, a nie wartościującym sensie relatywistyczna. Przedstawiona przez Gombrowicza sytuacja problematyzuje rozróżnienia na to, co altruistyczne i egoistyczne, odpowiedzialne i nieodpowiedzialne, sprawiedliwe i niesprawiedliwe. Czyż dziennikowy „Gombrowicz” w owej scenie nie jest bliski tej

W kategoriach „ironicznej pointy”, sprowadzającej scenę do konstatacji niemożności pomocy wszystkim cierpiącym, czyta zakończenie tej sceny w innym swoim tekście S. C h w in („Matnia” Gombrowicza. W: Samobójstwo jako doświadczenie wyobraźni. Gdańsk 2010, s. 380).

81 Z koncepcjami Rorty’ego i Baumana „ziarnistą” moralność Gombrowicza łączył A. S z a h aj (Ironia i miłość. Neopragmatyzm Richarda Rorty'ego w kontekście sporu o postmodernizm. Wrocław 2002, s. 215). 
szczególnej sytuacji, w jakiej znajdował się Abraham: jest bowiem tak samo jednocześnie absolutnie odpowiedzialny i absolutnie nieodpowiedzialny - odpowiedzialny wobec absolutnego zobowiązania pomocy, odpowiedzialny wobec każdego uratowanego żuka, i absolutnie nieodpowiedzialny w momencie przerwania pomocy i względem pierwszego nieuratowanego żuka ${ }^{82}$. Mimo to widzę w tym próbę wyjścia poza reaktywność, tzn. poza konstytuowanie pozytywności na tle uprzedniej negatywności (,żuk nieuratowany”), nie zaś jakiejś obłędnej arytmetyki nieustępliwości i skuteczności (,żuki uratowane”), ale w afirmacji decyzji i konieczności powodowanej wspólnotą doświadczenia. To w tym momencie opowiastka Gombrowicza jest najbardziej dotkliwa. Decyzja okazuje się zatem tyleż niemożliwa, co konieczna. Niemożność podjęcia bezproblemowej decyzji oznacza warunek możliwości podjęcia decyzji. Aporetyczność rozwiązania dylematu nie stanowi rezultatu jego złożoności, ale warunek możliwości wyboru. Kiedy wybór jest oczywisty, to w istocie nie jest wyborem. Z prawdziwym wyborem mamy do czynienia wyłącznie wówczas, gdy każdy werdykt okazuje się wątpliwy. Obowiązuje tu etyka niedająca się sprowadzić do uniwersalnych zasad, jakichś ogólnych imperatywów. Nie jest to zatem sytuacja, w której samoświadomy podmiot, znajdujący wsparcie w systemie metafizycznie umocowanych presupozycji moralnych, dokonuje suwerennego wyboru między tym, co dobre, a tym, co złe, tym, co właściwe, a tym, co niewłaściwe, tym, co rozumne, a tym, co nierozumne. Zostaje bez procedury działania, protokołu powinności, kodeksu wartości. To implikuje wyjście poza pozorną oczywistość rozwiązania, poza złudną jednoznaczność wyboru, poza oszukańczą pewność samoświadomości. Pewna jest tylko konieczność wzięcia odpowiedzialności za dokonany wybór, a czasem i nieznośna, nieredukowalna wątpliwość, czy on był słuszny, która pozostanie już na zawsze.

\author{
Abstract \\ MARIAN BIELECKI Univeristy of Wrocław \\ ORCID: 0000-0003-2490-0823
}

\title{
TOWARDS HERMENEUTICS AND IMPOSSIBLE ETHICS KAFKA AND GOMBROWICZ
}

The article interprets the famous scene from Witold Gombrowicz's Dziennik (Diary) in which the writer saves beetles on a beach. The episode is discussed in a comparative context (a similar scene in Kafka's diary), philosophical (Kantian morality), and theoretical (Derrida and animal studies). Following the argumentation offered in the article, Gombrowicz challenges the attempts at creating universal morality and suggests his own ethics in which the crucial meaning is given to the issues of individual decisions and personal responsibility.

Wydaje mi się, że Gombrowicz byłby bliski myśleniu S. C ritchley a (Nieustajace żadanie. Etyka polityczna. Przeł. R. D o b r ow ols ki, M. G u s i n. Wrocław 2006), dla którego doświadczenie etyczne poprzedzone zostaje działaniem moralnym, ponieważ stanowi jego siłe motywacyjną. Na początku jest niemożliwe żądanie i postawa zaangażowania, które w nieredukowalnie nieautentycznym i ekscentrycznym podmiocie tworzą rozdźwięk, będący w istocie głosem sumienia - dalekim jednak od nietzscheańskich i freudowskich konotacji. Dlatego Critchley pisze o „etyce niewygody”, będącej „hiperboliczną etyką opartą na internalizacji niemożliwego do spełnienia żądania etycznego”, a także o „wygórowanym żądaniu nieskończonej odpowiedzialności” z pełną świadomością, że temu żądaniu nikt „nigdy nie sprosta” (ibidem, s. 32, 92). 